\title{
IDENTIFICATION OF DISTINCT SOURCES OF RESISTANCE IN BLACK GRAM AGAINST ROOT- KNOT NEMATODE (MELOIDOGYNE INCOGNITA)
}

\begin{abstract}
Sudam Namdeo Varpe
Department of Agricultural Entomology,

Mahatma Phule Krishi Vidyapeeth, Rahuri, Ahemednagar - 413722, Maharashtra state (India)

Abstract- Screening of germplasm lines of black gram against root-knot nematode, Meloidogyne incognita were carried out under glasshouse condition during year, 201516. The experiment was conducted in pot for screening the twenty six germplasm lines of black gram against rootknot nematode; $M$. incognita. From the experiment it is revealed that none of the germplasm line was found to be resistant to the root knot nematode. Three germplasm lines viz, Phule-U-0011-1, KU-12-53 and BDU-1 were found to be moderately resistant. Rest of the germplasm lines was found either susceptible or highly susceptible to the pest.
\end{abstract}

Keywords- Black gram, Germplasm, Resistance, Screening, Root-knot nematode

\section{INTRODUCTION}

Pulses occupy an important position in Indian diet. Among pulses grown in India black gram is considered as an important pulse crop after chickpea, pigeon pea and mung bean. Its seeds are highly nutritious with protein (25-26\%), carbohydrates (60\%), fat (1.5\%), minerals, amino acids and vitamins (Anonymous, 1991). Such an important pulse crop is attacked by various insect and non insect pests. In addition to insect pests and diseases, plant parasitic nematodes have also become a limiting factor in successful cultivation of black gram. Among the several plant parasitic nematodes, root-knot nematode, M. incognita (Chitwood, 1949) is one of them causing damages in black gram and which effect on crop yield.

Nematode is difficult to control because it damages to crop in soil and it requires large amount of chemicals to apply which is uneconomical to the farmers. Most practical solution for controlling nematodes is only by developing resistant cultivars which to be cheaper and easily adoptable to the farmers. With considering the interest to find out the source of resistance in Black gram cultivar for giving recommendation to farmers for

\author{
Sandeep Machindra Pathare \\ Department of Agricultural Botany \\ Mahatma Phule Krishi Vidyapeeth, Rahuri \\ Ahemednagar - 413722, Maharashtra state (India)
}

cultivation and to the breeders for developing resistance against $M$. incognita in high yielding varieties this scientific study was carried out with objective to find out the distinct sources of resistance in black gram against $M$. incognita.

\section{MATERIAL AND METHODS}

Material

\section{Pure culture of $M$. incognita}

The pure culture of root-knot nematode was maintained in glasshouse as well as on field plots of AICRP on Nematodes, Department of Agricultural Entomology, MPKV, Rahuri by growing of Brinjal (cv. MBH-110) crop. This maintained culture was used for screening experiment under glasshouse conditions.

\section{Growth media}

As a growth media black soil was collected from the field of the AICRP on Plant Parasitic Nematodes, Department of Agricultural Entomology, MPKV, Rahuri. This soil was mixed with FYM in 3:1 proportion and this mixture after sieving was sterilized with steam at pressure $6.75 \mathrm{~kg} / \mathrm{cm}^{2}$ for four hours in soil sterilizer. This sterilized mixture was used as a growth medium for black gram seedling.

Pots

For screening of different germplasm lines of black gram, earthen pots which having $15 \mathrm{~cm}$ diameters were used. All earthen pots were clean with water and disinfected with 4 per cent formaldehyde solution.

\section{Black gram lines/varieties}

The different lines of black gram were obtained from the Oilseeds Specialist, ARS, Jalgaon for screening purpose. 


\section{Sowing}

The each sterilized earthen pots were filled with sufficient autoclaved soil mixture. Two seeds of each germplasm lines were sown in each pot. On germination kept only one plant per pot. In root knot nematode sick plots, two seeds of Brinjal (cv. MBH-110) were sown at per hill. Ten days on germination only kept single healthy seedling per hill.

\section{Nematodes extraction from soil}

Soil having nematode population was collected from the root zone of brinjal crops which grown continuously in pure culture field plots and processed by Cobb's Sieving and Decanting method (Cobb, 1918).

\section{Extraction of nematode egg masses}

Uprooted the Brinjal plants from earthen pots and the roots washed under tap running water and egg masses from these roots were removed in water. Such water was used for experimentation.

\section{Nematode suspension for inoculation}

The nematodes were collected by Cobb's Sieving and Decanting method was used for inoculation. Before inoculation, the nematodes per $\mathrm{ml}$ of suspension were determined. Desired number of nematodes was inoculated in pots by making holes in the soil.

Other facilities like microscopes, hot air oven, autoclave, glasshouse labours, laboratory sieves with different mesh (20, 60, 200 and 350 mesh) were required and provided by the Department of Agricultural Entomology, MPKV, Rahuri.

\section{Methods}

A statistically designed experiment was conducted during kharif season of the year 2015 in the glasshouse of AICRP on Nematodes, Department of Agricultural Entomology, MPKV, Rahuri to find out distinct sources of resistance in black gram against root knot nematode. The twenty six germplasm lines seed of black gram listed in Table 1 were obtained from the Oilseeds Specialist, ARS, Jalgaon. All germplasm lines were sown in $15 \mathrm{~cm}$ diameter earthen pots which containing $1 \mathrm{~kg}$ mixture of autoclaved soil and FYM in 3:1 proportion. Thinning was done on germination and kept to only one healthy seedling in each pot. Each pot with germplasm line was inoculated with 1000 freshly hatched juveniles of root-knot nematode. Stock culture of root-knot nematode was maintained on Brinjal in the earthen pots as well as in the field plots. Inoculation was done by pouring nematode suspension obtained from the egg masses of stock culture in holes prepared near the plants and on roots which exposed by removing the top layer soil, which was later covered by the moist autoclaved soil.

Nematode count per $\mathrm{ml}$ of suspension was taken before inoculation and required quantity of suspension poured into the pots. The plants were watered when required and given the recommended fertilizer dose.

The details of the experiment are given below,

\section{Details of experiment}

a. Design

b. Replications

c. Treatments

d. Date of sowing

e. Date inoculation

f. Date
termination

g. Fertilizers

Completely Randomized Block Design

03 (Three)

26 (Twenty six)

22.6 .2015

of : 02.7 .2015

of : 08.9 .2015

: i. Urea @ $20 \mathrm{~kg} \mathrm{~N} / \mathrm{ha}$

ii. Single super phosphate

@ $40 \mathrm{~kg} \mathrm{P}_{2} \mathrm{O}_{5} / \mathrm{ha}$

\section{Method of recording observations}

After seven week of culture inoculation, each germplasm line of black gram was uprooted carefully. The adhering soil was washed under clean tap water, then plant cut at the base and taking observations on number of root galls and egg masses present on roots. To count egg masses, the gall index 1 to 5 scale was worked out with considering the number of root galls and eggs masses/plant. The lines were categorized in different reactions on the basis of gall index as below.

\begin{tabular}{|c|c|c|}
\hline $\begin{array}{c}\text { Gall } \\
\text { Index }\end{array}$ & $\begin{array}{c}\text { No. of root galls } \\
\text { or egg } \\
\text { masses/plant }\end{array}$ & Reaction \\
\hline 1 & 0 & Highly resistant (HR) \\
\hline 2 & 1 to 10 & Resistant (R) \\
\hline 3 & 11 to 30 & Moderately resistant (MR) \\
\hline 4 & 31 to 100 & Susceptible (S) \\
\hline 5 & $>101$ & Highly susceptible (HS) \\
\hline
\end{tabular}

To count root-knot nematode population, Soil samples collected from the pots were proceeding by Cobb's Sieving and Decanting Method. The residues of 200 to 350 mesh sieves were collected in plastic beakers and the final volume of beaker was adjusted to $200 \mathrm{ml}$ by adding tap water. For nematode count, the average of ten counts of one $\mathrm{ml}$ suspension was taken and from this it was calculated to $200 \mathrm{ml}$ of suspension, which was the soil population in the pot. From this, the number of times of multiplication of nematodes was worked out by dividing final nematode population with initially inoculated nematode population.

\section{Analysis of experimental data}

To find out the significant difference in the different germplasm lines of black gram, the all data were statistically analyzed at 5 per cent level. 
Table 1. Black gram germplasm lines/varities screened against root-knot nematode, $M$. incognita

\begin{tabular}{|c|c|c|c|}
\hline Sr. No. & Germplasm line & Sr. No. & Germplasm line \\
\hline 1 & Vijay & 14 & PU-401-3 \\
\hline 2 & BDU-1 & 15 & PAU-1 \\
\hline 3 & Phule-U-003 & 16 & KU-12-33 \\
\hline 4 & Phule-U-504-4 & 17 & KU-12-37 \\
\hline 5 & Phule-U-0011-1 & 18 & KU-12-38 \\
\hline 6 & Phule-U-50214 & 19 & KU-12-40 \\
\hline 7 & AKU-10-1 & 20 & KU-12-42 \\
\hline 8 & AKU-10-6 & 21 & KU-12-43 \\
\hline 9 & AKU-15 & 22 & KU-12-52 \\
\hline 10 & TAU-2 & 23 & KU-12-53 \\
\hline 11 & TPU-4 & 24 & KU-12-54 \\
\hline 12 & PU-0014 & 25 & KU-12-56 \\
\hline 13 & PU-401-1 & 26 & KU-12-57 \\
\hline
\end{tabular}

\section{RESULTS AND DISCUSSION}

It could also be seen from the data presented in Table 2 that the initial nematode population in soil was $1000 \mathrm{~J}_{2} /$ pot and six to eight weeks after inoculation, the nematode population of moderately resistant lines was lower than the other susceptible and highly susceptible lines. The moderately resistant germplasm lines, Phule-U-0011-1, KU-12-53 and BDU-1 recorded the multiplication factor of 1.82, 1.83 and 1.92 respectively.

After seven week of inoculation the observations on root galls/egg masses was recorded and are presented in Table 3. It could be seen from the Table 3 and 4 that, out of twenty six germplasm lines of black gram none was found to be resistant to the root knot nematode. However, three lines viz., Phule-U-0011-1, KU-12-53 and BDU-1 were found to be moderately resistant to root-knot nematode recording 25.33 , 25.67 and 26.33 root galls/egg masses/plant respectively. The recorded gall index in these three lines was 3.00/ plant. Among the rest of twenty three germplasm lines, thirteen and ten were found susceptible and highly susceptible to root-knot nematode, respectively. The recorded number of root galls/egg masses in these lines ranged from 48.00 (KU-12-33) to 154.00 (KU-12-57) per plant. The recorded gall index in these lines ranged from 4.00 to $5.00 /$ plant. The all findings are in confirmation with Kofoid and White (1919), Gupta et. al. (1986), Das et. al. (1988), Mishra and Swain (1988), Chandel and Mehta (1992), Bhatti S. S. (1994), Chavda et. al.(1999), Mhase et al. (1999), Hassan and Devi (2004), Goel (2004) and Singh et al. (2006).
Table 2. Effect of different black gram cultivars/ lines on root-knot nematode, $M$. incognita population

\begin{tabular}{|c|c|c|c|c|c|c|c|}
\hline \multirow{2}{*}{$\begin{array}{l}\text { Sr. } \\
\text { No. }\end{array}$} & \multirow{2}{*}{$\begin{array}{l}\text { Germplasm } \\
\text { lines }\end{array}$} & \multirow{2}{*}{\begin{tabular}{|c|} 
Initial \\
nematode \\
population \\
$\left(\mathbf{J}_{2}\right) /$ pot \\
\end{tabular}} & \multicolumn{4}{|c|}{$\begin{array}{c}\text { Root-knot nematode population } \\
\left(\mathrm{J}_{2}\right) / \text { pot at end of experiment }\end{array}$} & \multirow{2}{*}{$\begin{array}{l}\text { Multiplication } \\
\text { factor }\end{array}$} \\
\hline & & & R-I & R-II & R-III & Mean & \\
\hline 1. & Vijay & 1000 & 2520 & 2480 & 2600 & 2533.33 & 2.53 \\
\hline 2. & BDU-1 & 1000 & 1940 & 1860 & 1960 & 1920.00 & 1.92 \\
\hline 3. & Phule-U-003 & 1000 & 2460 & 2420 & 2600 & 2493.33 & 2.49 \\
\hline 4. & $\begin{array}{l}\text { Phule-U- } \\
504-4 \\
\end{array}$ & 1000 & 2400 & 2400 & 2820 & 2540.00 & 2.54 \\
\hline 5. & $\begin{array}{c}\text { Phule-U- } \\
0011-1 \\
\end{array}$ & 1000 & 1860 & 1780 & 1820 & 1820.00 & 1.82 \\
\hline 6. & $\begin{array}{l}\text { Phule-U- } \\
50214 \\
\end{array}$ & 1000 & 2920 & 3320 & 3560 & 3266.66 & 3.26 \\
\hline 7. & AKU-10-1 & 1000 & 3020 & 2680 & 2760 & 2820.00 & 2.82 \\
\hline 8. & AKU-10-6 & 1000 & 3600 & 3480 & 3360 & 3480.00 & 3.48 \\
\hline 9. & AKU-15 & 1000 & 2860 & 2360 & 2580 & 2600.00 & 2.60 \\
\hline 10. & TAU-2 & 1000 & 2260 & 2820 & 2820 & 2633.33 & 2.63 \\
\hline 11. & TPU-4 & 1000 & 2920 & 2680 & 2560 & 2720.00 & 2.72 \\
\hline 12. & PU-0014 & 1000 & 2800 & 2700 & 2520 & 2673.33 & 2.67 \\
\hline 13. & PU-401-1 & 1000 & 3660 & 2820 & 3220 & 3233.33 & 3.23 \\
\hline 14. & PU-401-3 & 1000 & 2960 & 2520 & 2720 & 2733.33 & 2.32 \\
\hline 15. & PAU-1 & 1000 & 3280 & 3680 & 3340 & 3433.33 & 3.43 \\
\hline 16. & KU-12-33 & 1000 & 2260 & 2320 & 2220 & 2266.66 & 2.26 \\
\hline 17. & KU-12-37 & 1000 & 3320 & 3440 & 3680 & 3480.00 & 3.48 \\
\hline 18 & KU-12-38 & 1000 & 2420 & 2560 & 2520 & 2500.00 & 2.50 \\
\hline 19. & KU-12-40 & 1000 & 3200 & 3520 & 2760 & 3160.00 & 3.16 \\
\hline 20. & KU-12-42 & 1000 & 2580 & 2620 & 2620 & 2606.66 & 2.60 \\
\hline 21. & KU-12-43 & 1000 & 2720 & 2960 & 3280 & 2986.66 & 2.98 \\
\hline 22. & KU-12-52 & 1000 & 2880 & 2820 & 2800 & 2833.33 & 2.83 \\
\hline 23. & KU-12-53 & 1000 & 1780 & 1820 & 1900 & 1833.33 & 1.83 \\
\hline 24. & KU-12-54 & 1000 & 2980 & 3200 & 2920 & 3033.33 & 3.03 \\
\hline 25. & KU-12-56 & 1000 & 2580 & 2560 & 2620 & 2586.66 & 2.58 \\
\hline \multirow[t]{3}{*}{26.} & KU-12-57 & 1000 & 3860 & 3580 & 3420 & 3620.00 & 3.62 \\
\hline & S.E. \pm & & & & & 118.79 & \\
\hline & $\mathrm{CD}$ at $5 \%$ & & & & & 337.44 & \\
\hline
\end{tabular}


International Journal of Engineering Applied Sciences and Technology, 2020

Vol. 5, Issue 5, ISSN No. 2455-2143, Pages 95-99

Published Online September 2020 in IJEAST (http://www.ijeast.com)

Table 3. Reaction of different cultivars/lines of black gram against root-knot nematode, $M$. incognita as evidenced by number of root-galls/egg masses/plant

\begin{tabular}{|c|c|c|c|c|c|}
\hline \multirow{2}{*}{$\begin{array}{c}\text { Sr. } \\
\text { No. }\end{array}$} & \multirow{2}{*}{ Germplasm lines } & \multicolumn{3}{|c|}{ Number of root galls/egg masses/ } & \multirow{2}{*}{ Mean } \\
\cline { 3 - 5 } & & R-I & R-II & R-III & \\
\hline 1. & Vijay & 97 & 65 & 54 & 72.00 \\
\hline 2. & BDU-1 & 28 & 27 & 24 & 26.33 \\
\hline 3. & Phule-U-003 & 56 & 62 & 86 & 68.00 \\
\hline 4. & Phule-U-504-4 & 74 & 85 & 65 & 74.66 \\
\hline 5. & Phule-U-0011-1 & 20 & 27 & 29 & 25.33 \\
\hline 6. & Phule-U-50214 & 122 & 105 & 92 & 106.3 \\
\hline 7. & AKU-10-1 & 127 & 132 & 104 & 121.0 \\
\hline 8. & AKU-10-6 & 148 & 132 & 162 & 147.3 \\
\hline 9. & AKU-15 & 94 & 76 & 67 & 79.00 \\
\hline 10. & TAU-2 & 68 & 87 & 104 & 86.33 \\
\hline 11. & TPU-4 & 112 & 94 & 88 & 98.00 \\
\hline 12. & PU-0014 & 83 & 89 & 102 & 91.33 \\
\hline 13. & PU-401-1 & 139 & 115 & 127 & 127.0 \\
\hline 14. & PU-401-3 & 122 & 82 & 94 & 99.33 \\
\hline 15. & PAU-1 & 152 & 138 & 140 & 143.3 \\
\hline 16. & KU-12-33 & 57 & 37 & 50 & 48.00 \\
\hline 17. & KU-12-37 & 162 & 144 & 155 & 153.6 \\
\hline 18 & KU-12-38 & 78 & 104 & 82 & 88.00 \\
\hline 19. & KU-12-40 & 140 & 128 & 98 & 122.0 \\
\hline 20. & KU-12-42 & 78 & 106 & 84 & 89.33 \\
\hline 21. & KU-12-43 & 132 & 107 & 96 & 111.6 \\
\hline 22. & KU-12-52 & 97 & 124 & 95 & 105.3 \\
\hline 23. & KU-12-53 & 26 & 24 & 27 & 25.67 \\
\hline 24. & KU-12-54 & 133 & 97 & 128 & 119.3 \\
\hline 25. & KU-12-56 & 76 & 75 & 106 & 85.66 \\
\hline 26. & KU-12-57 & 140 & 148 & 174 & 154.0 \\
\hline & S.E. \pm & & & & 8.45 \\
\hline & CD at5 \% & & & & 24.00 \\
\hline
\end{tabular}

Table 4. Reaction of different cultivars/lines of black gram against root-knot nematode, $M$. incognita as evidenced by gall index/plant

\begin{tabular}{|c|c|c|c|c|c|c|}
\hline \multirow{2}{*}{$\begin{array}{l}\text { Sr. } \\
\text { No. }\end{array}$} & \multirow{2}{*}{ Germplasm lines } & \multicolumn{3}{|c|}{ Gall index/plant } & \multirow[t]{2}{*}{ Mean } & \multirow[t]{2}{*}{ Reaction } \\
\hline & & R-I & R-II & R-III & & \\
\hline 1. & Vijay & 4 & 4 & 4 & 4.00 & $\mathrm{~S}$ \\
\hline 2. & BDU-1 & 3 & 3 & 3 & 3.00 & MR \\
\hline 3. & Phule-U-003 & 4 & 4 & 4 & 4.00 & $\mathrm{~S}$ \\
\hline 4. & Phule-U-504-4 & 4 & 4 & 4 & 4.00 & $\mathrm{~S}$ \\
\hline 5. & Phule-U-0011-1 & 3 & 3 & 3 & 3.00 & MR \\
\hline
\end{tabular}

\begin{tabular}{|c|c|c|c|c|c|c|}
\hline 6. & Phule-U-50214 & 5 & 5 & 4 & 4.66 & HS \\
\hline 7. & AKU-10-1 & 5 & 5 & 5 & 5.00 & HS \\
\hline 8. & AKU-10-6 & 5 & 5 & 5 & 5.00 & HS \\
\hline 9. & AKU-15 & 4 & 4 & 4 & 4.00 & S \\
\hline 10. & TAU-2 & 4 & 4 & 5 & 4.33 & S \\
\hline 11. & TPU-4 & 5 & 4 & 4 & 4.33 & S \\
\hline 12. & PU-0014 & 4 & 4 & 5 & 4.33 & S \\
\hline 13. & PU-401-1 & 5 & 5 & 5 & 5.00 & HS \\
\hline 14. & PU-401-3 & 5 & 4 & 4 & 4.33 & S \\
\hline 15. & PAU-1 & 5 & 5 & 5 & 5.00 & HS \\
\hline 16. & KU-12-33 & 4 & 4 & 4 & 4.00 & S \\
\hline 17. & KU-12-37 & 5 & 5 & 5 & 5.00 & HS \\
\hline 18 & KU-12-38 & 4 & 5 & 4 & 4.33 & S \\
\hline 19. & KU-12-40 & 5 & 5 & 4 & 4.66 & HS \\
\hline 20. & KU-12-42 & 4 & 5 & 4 & 4.33 & S \\
\hline 21. & KU-12-43 & 5 & 5 & 4 & 4.66 & HS \\
\hline 22. & KU-12-52 & 4 & 5 & 4 & 4.33 & S \\
\hline 23. & KU-12-53 & 3 & 3 & 3 & 3.00 & MR \\
\hline 24. & KU-12-54 & 5 & 4 & 5 & 4.66 & HS \\
\hline 25. & KU-12-56 & 4 & 4 & 5 & 4.33 & S \\
\hline 26. & KU-12-57 & 5 & 5 & 5 & 5.00 & HS \\
\hline & S.E. \pm & & & & 0.25 & \\
\hline & CD at 5 \% & & & & 0.73 & \\
\hline
\end{tabular}

\section{CONCLUSION}

Total twenty six germplasm lines of black gram were screened against root-knot nematode, $M$. incognita. Out of these none of the germplasm line was found to be resistant to the root knot nematode. However, three germplasm lines of black gram viz., Phule-U-0011-1, KU-12-53 andBDU-1 were found to be moderately resistant. Remaining all germplasm lines were found either susceptible or highly susceptible to the root knot nematode.

\section{ACKNOWLEDGEMENT}

We would like to thank Dr. A.R. Walunj, Assistant professor, Department of Agricultural Entomology and Dr. A. M. Navale, Professor, Department of Plant Pathology and Agricultural Microbiology, M.P.K.V., Rahuri for their valuable guidance and support during the entire course of investigation of this project. 


\section{International Journal of Engineering Applied Sciences and Technology, 2020 \\ Vol. 5, Issue 5, ISSN No. 2455-2143, Pages 95-99 \\ Published Online September 2020 in IJEAST (http://www.ijeast.com)}

\section{REFERENCE}

1. Anonymous, 1991. Food and Agriculture Organization (FAO) Rome. Quarterly Bull. Of Statistics. 4 (2): 57.

2. Bhatti, S.S. 1994. Screening of mungbean and chickpea cultivars/varieties/lines against root-knot nematode. Pl. Protec. Bull. (Faridabad).46 (2):35-36.

3. Chavda,J.C., Patel, B.A. and Patel, D.J.1999. Screening of mung bean lines against M.incognita and M. javanica. Indian J. Nematol. 29 (1):109-110.

4. Chitwood, B.G. 1949. Root-knot nematodes. Part-I.A revision of the genus M. goeldi, 1987. Proc. Helm. Soc. Wash.16 :90-104.

5. Cobb, N. A. 1918. Estimating the nematode population of soil U.S. Dep. Agric. Bur. Plant Industry Tech. Circ. No. 1, pp. 48.

6. Chandel, Y. S. and Mehta, P. K 1992. Damaging threshold levels and evaluation of blackgram varieties against root knot nematode, Meloidogyne incognita. Indian J. Pl. Protec. 20 (2): 226-228.

7. Das, P., Sarmah, D. K. and Phukan, P. N. 1988. Reaction of some pulse varieties to root-knot nematode. Indian J. Nematol. 18(1):116.

8. Goel, S. R. 2004. Reaction of certain urdbean (Vigna mungo L.) genotypes to root-knot nematode, Meloidogyne javanica and Meloidogyne incognita. Ann. Agril. Res. 25 (4): 626-627.

9. Gupta, D. C., Paruthi, I.J. and Verma, K. K. 1986. Reaction of mung bean germplasms and its pathogenicity against M.javanica.Indian J. Nematol. 16(2):194-196.

10. Hassan, M. G. and Devi, S. 2004. Evaluation of mung bean, urd bean, lentil and chickpea germplasm for resistance to root-knot nematode. Indian J. Nematol. 34 (2):228-229.

11. Mishra, S. K. and Swain, P. K. 1988. Reaction of some mung bean lines to root knot nematode. Indian $\mathrm{J}$. Nematol.18 (2):348-349.

12. Mahapatra, S. N. and Swain, P. K. 1999. Avoidable yield loss due to $M$. incognita and Fusarium oxysporum in blackgram.Indian J. Nematol. 29 (1):87-89.

13. Mhase, N. L., Mote, U .N., Shelke, S. S. and Kadam, D. B. 1999. Evaluation of varieties/lines of pulse crops against root-knot nematode, Meloidogyne incognita race2. Indian J. Nematol. 29 (1): 91-92

14. Singh, B., Kumar, S. and Gupta, S. 2006.Screening of cultivated and wild germplasm of urd bean against root knot nematode, Meloidogyne javanica. Indian J. Pulse Res. 19 (1): 101-103. 